\title{
Left Unheard: Detecting Mood and Aggression Through Ostracism and Trait Mindfulness
}

\author{
Cleoputri Yusainy, Putri Intan Mila Karti, Roynaldo Ramadhani Ikhsan, \& Ziadatul Hikmiah \\ Department of Psychology, Faculty of Social and Political Sciences \\ Universitas Brawijaya
}

\begin{abstract}
Ostracism occurs in the real world but causal investigation of the effect of ostracism on antisocial behavior (i.e., aggression) is typically limited by ethical consideration. This lab-based study ( $N=131$ Indonesian undergraduates) replicated and extended Chester and DeWall's (2016) work by: (1) measuring the impact of ostracism on direct physical aggression rather than symbolic form of aggression; (2) investigating the role of trait mindfulness as a potential emotion regulation mechanism to replace the mood-improving qualities in aggression; and (3) employing a non-Western sample. We found that after being involved in the CRTT, ostracized participants mood had recovered at least in terms of negative affect. Aggression might have been seen as justifiable once it was followed by an act of restoring control of to not damage the ostracizer's reputation afterwards. Moreover, we found that trait mindfulness could buffer negative reactions to ostracism by reducing aggressiveness once the negative affect was higher. As a whole, this study may provide a useful framework on whether and when the mechanism of mood improvement as well as individual differences in mindfulness could be incorporated into the intervention strategies for preventing ostracism-related aggression before escalating to violence.
\end{abstract}

Keywords: aggressive behavior, emotion regulation, mood, ostracism, trait mindfulness

Pengucilan (awam: "dikacangin") jamak terjadi di kehidupan nyata namun telaah kausal atas pengaruh pengucilan terhadap perilaku antisosial (agresi) secara umum terbentur pertimbangan etika. Studi berbasis laboratorium ini $(N=131$ mahasiswa $S 1)$ mereplikasi dan memperluas penelitian Chester and DeWall (2016) melalui: (1) pengukuran dampak pengucilan terhadap agresi fisik alih-alih agresi berwujud simbolis, (2) kajian peran sifat-kesadaran penuh sebagai suatu mekanisme regulasi emosi yang berpotensi untuk menggantikan kualitas perbaikan suasana hati dalam agresi, dan (3) pelibatan sampel non-Barat. Sebagaimana ditemukan dalam penelitian ini, setelah dilibatkan dalam CRTT, suasana hati partisipan yang diberikan perlakuan pengucilan terpulihkan afek negatifnya. Agresi dianggap sebagai hal yang lumrah sepanjang diikuti oleh tindakan yang mampu mengendalikan untuk tidak membahayakan reputasi pelaku pengucilan. Lebih jauh, penelitian ini juga menemukan bahwa sifat-kesadaran penuh dapat menangkis reaksi negatif atas pengucilan melalui pengurangan agresivitas ketika afek negatif tinggi. Secara keseluruhan, studi ini mampu menjawab apa dan kapan perbaikan mekanisme suasana hati, juga perbedaan individual dalam kesadaran penuh dapat diterapkan sebagai strategi intervensi dalam pencegahan agresi berbasis pengucilan sebelum bermanifestasi menjadi tindak kekerasan.

Kata kunci: perilaku agresif, regulasi emosi, suasana hati, pengucilan, sifat-kesadaran penuh

Figuring out the meaning of social interaction enables us to respond to others appropriately. This reliance on social inclusion resulted in humans' developing an internal monitoring system to detect social exclusion (Williams, Forgas, von Hippel, \& Zadro, 2005). Without adequate social connection, the world

Correspondence concerning this article should be addressed to Cleoputri Yusainy, Department of Psychology, Faculty of Social and Political Sciences Universitas Brawijaya. E-mail: cleo.yusainy@ub.ac.id would be perceived as a dangerous place. More than 500 studies in neuroscience synthesized that social exclusion causes as much pain as physical injury, thirst, and hunger (see Kross, Berman, Mischel, Smith, $\&$ Wager, 2011). Two types of social exclusion have been identified, namely direct negative attention conveying relational devaluation (i.e., rejection-based) and passive ignorance (i.e., ostracism-based; Wesselmann $\&$ Williams, 2017). The focal point of the current 
study is on ostracism-based experience ("dikacangin" - Id.).

Ostracism-based experiences involve someone (i.e., the ostracized) being explicitly ignored while in another's presence either physically or digitally as well as via nonverbal cue such as not being given eye contact, being forgotten, or facing uncomfortable silences (Williams, 2009). In Williams' (2009) temporal needthreat model, ostracism begins with a reflexive (or immediate) stage when the pain detected in the dorsal anterior cingulate cortex (dACC) increases negative affect and threatens the four fundamental needs of belonging, self-esteem, control, and meaningful existence. Next, the ostracized enters a reflective (or delayed) stage when he or she tries to understand and overcome the pain through three possible behavioral responses: antisocial (moving against; e.g., aggression), prosocial (moving towards; e.g., conformity), or moving away (e.g., seeking solitude). If ostracism prolongs, the ostracized will decline into a resignation stage, thereby making himself or herself feels alienated, depressed, helpless, and worthless.

Restraining the self from behaving aggressively in response to ostracism is socially desirable, but at the same time can be difficult. On a mass scale, acute or chronic social rejection predicts about $80 \%$ of school shootings in the United States (Leary, Kowalski, Smith, \& Phillips, 2003). A similar rate of prediction is concluded across 13 countries, including our neighboring country i.e., Thailand (Sommer, Leuschner, \& Scheithauer, 2014). This latter finding is quite unexpected since cross-cultural studies typically show that individuals from a culture that emphasizes maintaining social harmony (associated with Eastern and collectivist cultures) are less likely to resort to direct methods of aggression than those from individualistic cultures (e.g., Forbes, Zhang, Doroszewicz, \& Haas, 2009). In Western countries, many lab-based studies have documented a direct link between ostracism and aggression (Ren, Wesselmann, \& Williams, 2018). The underlying motives for ostracism-related aggression, however, are still inconclusive. Negative emotion, one of the critical mechanisms in Williams' (2009) model, is sometimes substituted with dampened emotions (for a meta-analysis see Blackhart, Nelson, Knowles, \& Baumeister, 2009), thus allowing the ostracized's responses to occur with no contribution from emotions. In contrast, another meta-analysis of social exclusion experiment concludes that exclusion does make people feel worse (Gerber \& Wheeler, 2009). Indeed, clarifying the role of negative emotions is vital to open up the possibilities of replacing aggressive responses with the more adaptive emotion regulation strategies to ostracism.

As an attempt to resolve controversy on the role of negative affect on ostracism-related aggression, Chester and DeWall (2016) suggested that negative affect would be more pronounced under acute, rather than chronic, instances of ostracism. In a series of acute ostracism experiments using the Cyberball paradigm (Williams, Cheung, \& Choi, 2000), they demonstrated that a symbolic form of aggression (i.e., stabbing pins in a Voodoo Doll Task) had (1) restored ostracized participants' levels of positive and negative affect to similar levels reported by the inclusion counterparts, and (2) consistently led to increases in positive affect but had less of an effect on post-aggression negative affect. They propose that people may respond aggressively towards acute ostracism not only because of negative affect per se but also due to the desire to return to affective homeostasis. As the actual harm is never intended to be delivered in the Voodoo Doll Task (McCarthy \& Elson, 2018), in the current study we replace this task with the Competitive Reaction-Time Task (CRTT: Taylor, 1967). The CRTT, also known as the Taylor Aggression Paradigm (TAP), has been used in many experiments on the effect of ostracism on direct physical aggression (e.g., Beyer, Münte, \& Krämer, 2014; Twenge, Baumeister, Tice, \& Stucke, 2001). The CRTT measures how much unpleasant and even harmful noise a participant is willing to administer to a bogus opponent in a disguised computer-based reaction-time task. In this way, we are able to scrutinize the extent to which aggressive behavior meets the mood-improvement goals for ostracized individuals in a more typical form of aggression.

Further, Chester and DeWall (2016; see also Denson, 2015) suggest (but had not examined) a form of emotion regulation that can potentially replace the moodimproving qualities in aggression, namely mindfulness ("sadar penuh hadir utuh" -Id. [Silarus, 2015]). A preliminary study of brief induction of mindfulness showed that although ostracized participants reported lower level of the need satisfaction compared to included participants, greater need recovery was shown amongst ostracized participants who received mindfulness induction (Molet, Macquet, Lefebvre, \& Williams, 2013). In Indonesia, the efficacy of brief mindfulness induction has been reported separately as an emotion regulation strategy (Yusainy, Nurwanti, et al., 2018) and as a counteracting mechanism of the effect of depleted self-control on aggressive behavior as measured in the CRTT (Yusainy \& Wicaksono, 2019). Nevertheless, the potential role of mindfulness on 
mood repair and aggression may also be investigated in the trait level.

Mindfulness as a trait refers to an inherent quality of attention to and awareness of daily experience (Brown \& Ryan, 2003). Since mindful attention is given on the task at hand, it allows one to fully experience one's own content of consciousness (e.g., negative affect) simply as an ephemeral state. As a result, mindfulness may lead to extinction of the habit of responding in reactive ways (Baer, 2003). Prior studies also show that trait mindfulness and mindfulness intervention can reduce negative automatic thoughts regarding one's self, as well as strengthen the capacity to let go of negative thoughts (Frewen, Evans, Maraj, Dozois, \& Partridge, 2008). Although those with low trait self-esteem often perceive ostracism-based experiences as more threatening, this effect has been shown to be moderated by trait mindfulness (Kong, 2016). Trait mindfulness is also crucial in predicting aggression (Yusainy \& Lawrence, 2014). Taken together, findings from the aforementioned research suggest that trait mindfulness may generate a specific prediction on who is less likely to use aggression as an emotion regulation strategy to ostracism.

To these ends, we predicted that: (1) Compared to those being included, ostracized participants would report lower post-ostracism positive affect and higher post-ostracism negative affect; (2) Aggression could restore ostracized participants' mood (i.e., positive and negative affect) to their baseline level; (3) Changes in post-aggression mood would be mediated by postostracism negative affect and aggressive behavior; and (4) Trait mindfulness could moderate the link between change in post-ostracism negative affect and aggressive behavior amongst ostracized participants.

\section{Methods}

\section{Participants and Procedures}

We obtained approval from local ethics committee to conduct this study. Potential participants from B University in Indonesia were recruited from an introductory psychology subject to participate in an experiment on "reaction-time competition". Participants were assigned with a random order generator to each of the ostracized vs. inclusion between-subject group. Our study was able to recruit 133 undergraduates, but two of them were discarded due to failure to obey to the experimental procedures, resulting in 131 final participants (101 females) with mean age of 18.04 (SD
$=.52)$. Participants were compensated with course's credit and a chance to win small amounts of incentive for three participants with the fastest reaction-time.

Participants signed consent, completed demographic information, and responded to self-reported measure of mindfulness and baseline mood. They were informed that they would perform the first task (i.e., the ostracism task) with two partners over the Intranet. The experimenter then announced that he or she needed to leave the room for a while ostensibly to prepare the participants' partners, and then after a while returned to inform that the partners were now ready. The participants were left alone to perform the task. Afterwards, they were asked to complete the second mood measure and manipulation check for the ostracism task.

Next, the participants performed the second task (i.e., the aggression task) and were left alone again. Then they completed the third mood measure, and finally were probed for suspicions and debriefed.

\section{Materials and Apparatus}

Ostracism task. As one the most common in-vivo paradigms of ostracism, Cyberball is more efficient and less traumatic than other ostracism paradigms (see Williams, 2007). The task has demonstrated strong internal validity and has been used in more than 120 studies (Hartgerink, van Beest, Wicherts \& Williams, 2015). We used Williams et al. (2000) Cyberball version 5.4.0.2 (http://www.empirisoft.com/cyberball.aspx), in which participants were convinced that two partners would be playing a 5-minute ball-tossing game with them over the Intranet. We told them that (1) the game was beneficial to improve their mental visualization skills before they entered the actual competition (i.e., the CRTT), (2) it was advisable to use the game to assist them in visualizing what the other players look like, what sort of people they are, the setting of the game, the atmosphere of the game, and (3) their performance in the Cyberball did not matter. Because the Cyberball is designated to create an ostracism condition prior to the actual competition, no scores would be gained from the game itself.

Participants in the ostracism group received the ball twice from the partners, whereas participants in the inclusion group received substantially more (i.e., one-third of the total number of ball throws). The time lag for throwing a ball between two computer players was arranged randomly at $900-4300 \mathrm{~ms}$, while the time lag of the participants to throw the ball was determined by themselves (Sleegers, Proulx, \& Beest, 2016). Immediately following the Cyberball game, 
we asked participants to respond to two statements, "I was ignored" and "I was excluded" on a 7-point scale $(1=$ not at all and $7=$ extremely). The scores were averaged to check the efficacy of the manipulation, such that higher scores indicated higher feelings of ostracism.

Aggression task. The CRTT (Taylor, 1967) has been used in at least 130 publications to ostensibly measure how much harmful noise an individual is willing to administer to a fictitious partner (Elson, 2016; McCarthy \& Elson, 2018), including in Indonesian undergraduates (Yusainy \& Wicaksono, 2019). We presented the task in Inquisit 5 (https://www.milli second.com/download/library/competitivereactionti$\mathrm{me} /$ ). Participants were told that they were playing a reaction-time game against one of the partners from the prior Cyberball. At the beginning of each trial $(n$ total $=25)$, they set the volume (level $1=60 \mathrm{db}$ to 10 $=105 \mathrm{db}$ ) and duration (level $1=0.5 \mathrm{~s}$ to $10=2.0 \mathrm{~s}$ ) of a noise blast that would be delivered when the partner lost. We also provided a non-aggressive option with volume $=0 \mathrm{db}$ and duration $=0 \mathrm{~s}$. We asked participants to click the left computer mouse as quickly as possible once the color in the box presented on their computer screen changed from yellow to red. The loser of each trial was a noise blast through surround earphones at the volume and duration settings made by the winner at the corresponding trial.

As our main purpose was to measure the immediate effect of ostracism, we used only the first trial in the CRTT (see e.g., Anderson \& Anderson, 2008; Twenge et al., 2001; Yusainy \& Lawrence, 2015). Specifically, the sum of noise volume and duration of this first trial was used as an aggression composite. In this form, participants' aggressive behavior was unprovoked to avoid any confounding effects of provocation during the later trials.

In order to demonstrate some validity for the CRTT, we asked participants to rate how unfair, aggressive, and less skilful their opponent was during the task on a 5 -point scale $(1=$ completely disagree and $5=$ completely agree). Prior to the CRTT, participants were told that their judgment would help the experimenter decide whether to use the opponent in future studies with payment or not, and that their evaluation would be kept confidential. The scores were averaged to create a rating of opponent's reputation damage (Lawrence $\&$ Hutchinson, 2014). In the current study, we expected higher rating to be positively correlated to the first trial aggression composite in the CRTT.

Mood. Amongst dimensional models of emotion derived from self-reported mood, the two-factor struc- ture of positive affect and negative affect developed by Watson and Tellegen (1985) remains to be the most popular. The Positive Affect, Negative Affect Schedule (PANAS: Watson, Clark, \& Tellegen, 1988) consists of two 10-item mood scales on positive affect (i.e., a state of enthusiastic, active, and alert; 10 items, e.g., "interested") and negative affect (i.e., a state of subjective distress and unpleasurable; 10 items, e.g., "irritable"). Participants rated on a 5-point scale (1 $=$ very slightly or not at all and $5=$ extremely) the extent to which they experienced each mood state. The PANAS was given at three time-points: (1) at baseline, (2) after the Cyberball game, and (3) after the CRTT. Internal reliabilities in the current sample were $\alpha=.84, .87, .88$ for positive affect and $.84, .87, .87$ for negative affect at baseline, post-ostracism, and post-aggression, respectively.

Trait mindfulness. The Mindfulness Attention Awareness Scale (MAAS: Brown \& Ryan, 2003) consists of 15 items on the absence of attention to and awareness of the present reality in daily life (e.g., "I find myself preoccupied with the future or the past") on a 6-point Likert-scale $(1=$ almost always and $6=$ almost never). The scale was designed to exclude any constructs of attitudinal, motivational, and well-being that are often overlapped with trait mindfulness. Many studies have reported the predictive validity of the scale (Sauer et al., 2013). Internal reliability of the MAAS in Indonesian undergraduates ranges from $\alpha=.76$ (Yusainy, Chan, Hikmiah, \& Anggono, 2019) to .81 (Yusainy, Ilhamuddin et al., 2018). In the current sample, we obtained $\alpha=.81$. The MAAS was given prior to the baseline PANAS.

\section{Results}

\section{Descriptive Statistics and Manipulation Checks}

Trait mindfulness $(M=3.72, S D=.63)$ was associated with lower negative affect at baseline $(M=$ $1.68, S D=.60 ; r=-.20, p=.02)$, post-ostracism $(M=$ $1.70, S D=.67 ; r=-.19, p=.03)$, and post-aggression $(M=1.72, S D=.69 ; r=-.31, p<.001)$, respectively. It was also related to higher positive affect post-ostracism $(M=2.95, S D=.80 ; r=.20, p=.02)$ but was only marginally related to positive affect at baseline $(M=$ $3.08, S D=.65 ; r=.16, p=.07, \mathrm{~ns}$.) and post-aggression $(M=3.37, S D=.63 ; r=.16, p=.06$, ns. $)$. These indicated that trait mindfulness had a potential to influence the dynamics of participants' mood, particularly negative affect. Trait mindfulness, however, 
was not related to aggressive behavior $(r=-.004, p$ $=.97$, ns.).

Aggressive behavior $(M=10.29, S D=.55)$ was positively related to participants rating of opponent's reputation damage during the task $(M=2.83, S D$ $=.64 ; r=.18, p=.04)$. Supporting the validity of CRTT, participants who were more aggressive also rated their opponent as being more unfair, aggressive, and less skilful.

After being ostracized, participants in the ostracism condition $(n=65)$ reported feeling more ignored and rejected than the inclusion condition $(n=66$; $t(129)=7.36, p<.0001 ; M$ ostracized $=5.81, S D=$ 1.75 vs. $M$ included $=3.49, S D=1.79$ ). Additionally, they also reported feeling lower in positive affect $(t(129)=-3.78, p<.0001 ; M$ ostracized $=2.69, S D$ $=.75$ vs. $M$ included $=3.20, S D=.77$ ) and higher in negative affect $(t(129)=2.01, p=.05 ; M$ ostracized $=1.81, S D=.67$ vs. M included $=1.58, S D=.64$ ) than included participants. Thus, the ostracism manipulation was successful in inducing differences between conditions in self-reported ostracized feeling and mood in the expected direction.

\section{Analysis of Mood-Repair}

To examine the effect of ostracism on mood (i.e., positive and negative affect) at three time points, we conducted a 2 (ostracism: inclusion vs. ostracism) X 2 (valence: positive vs. negative) X 3 (time-point: baseline vs. post-ostracism vs. post-aggression) mixed-effects general linear model on participants' mood report (see Table 1). The three-way interaction between ostracism $\mathrm{X}$ valence $\mathrm{X}$ time-point on mood was significant $(F(2,128)=12.59, p<.001)$.

Planned contrasts revealed that at the beginning of the experiment, the two conditions (i.e., inclusion vs. ostracism) were equivalent on measures of baseline positive affect $(F(1,129)=.02, p=.89$, ns. $)$ and negative affect $(F(1,129)=.04, p=.84$, ns. $)$. As predicted in Hypothesis 1, after the ostracism manipulation,

Table 1

Mixed-effects General Linear Model on

Participants' Mood $(d f=1,129)$

\begin{tabular}{lrr}
\hline \multicolumn{1}{c}{ Effect } & \multicolumn{1}{c}{$F$} & \multicolumn{1}{c}{$p$} \\
\hline Ostracism (between) & 2.80 & .100 \\
Valence (within) & 307.44 & $<.001$ \\
Time-point (within) & 24.85 & $<.001$ \\
Ostracism X valence & 4.60 & .030 \\
Ostracism X time-point & 4.41 & .020 \\
Valence X time-point & 15.17 & $<.001$ \\
Ostracism X valence X time-point & 12.59 & $<.004$ \\
\hline
\end{tabular}

ostracized participants were lower in positive affect $(F(1,129)=14.26, p<.001)$ and higher in negative affect $(F(1,129)=4.06, p=.05)$ than included participants. As predicted in Hypothesis 2, after the aggression task, ostracized participants positive affect $(F(1,129)=2.55, p=.11)$ and negative affect $(F(1,129)=.16, p=.69)$ returned to their baseline levels. While included participants post-aggression negative affect also returned to their baseline $(F(1,129)$ $=.49, p=.48)$, their post-aggression positive affect increased $(F(1,129)=42.62, p<.001)$. From the visual comparison of mood between conditions at three time points (Figure 1), it can be suggested that being aggressive reduced negative affect and increased positive affect for ostracized participants but increased both positive and negative affect for included participants.

\section{Mechanism of Mood-Repair}

Unusually, participants in the ostracism condition were equally aggressive compared to inclusion condition $(t(129)=-.92, p=.36$, ns.; $M$ ostracized $=$ $10.74, S D=5.52$ vs. $M$ included $=9.85, S D=5.55$ ). Given the positive association between aggressive behavior and participants' rating of their opponent during the CRTT, we tried to establish whether this rating could moderate the impact of ostracism on aggressive behavior. To do so, we performed a bootstrapped simple moderation model (PROCESS v3.3. "Model 1: Hayes, 2019, based on 5,000 resamples with $95 \%$ bias-corrected CI). Statistical significance would be inferred if the confidence interval for an effect does not include zero. We found that reputation damage rating of opponent moderated the effect of ostracism on aggressive behavior $(B=-3.67, S E=$ $1.50,95 \%$ CI $[-6.63,-.71])$. A simple slope test (see Figure 2) revealed that the effect of ostracism on aggressive behavior was positive when rating of opponent was low (-1 SD; $B=3.12, S E=1.35,95 \%$ CI [.47, 5.81]) but non-significant when rating of opponent was high $(+1 \mathrm{SD} ; B=-1.56, S E=1.33,95 \%$ CI [-4.20, $1.08]$, ns.). We decided to include this rating as covariate in the next serial mediation analyses.

Bootstrapped serial mediation models (PROCESS v3.3. "Model 6: Hayes, 2019) were performed to examine whether the temporal sequence through which post-ostracism aggression would enable participants to recover from negative affect immediately after being ostracized (Hypothesis 3). In each model with 5,000 bias-corrected bootstrap resamples, change in post-ostracism negative affect and then aggressive 

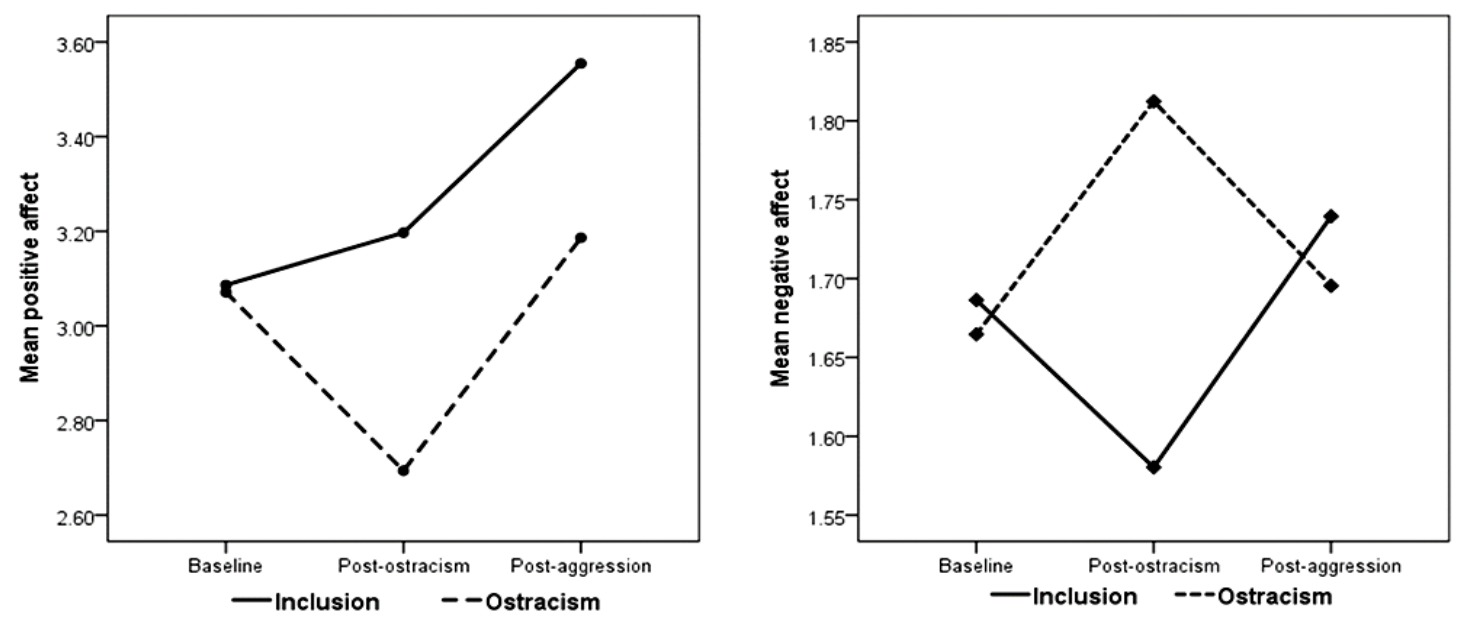

Figure 1. Comparison between ostracism conditions in self-reported mood at baseline, after ostracism manipulation, and after aggression task.

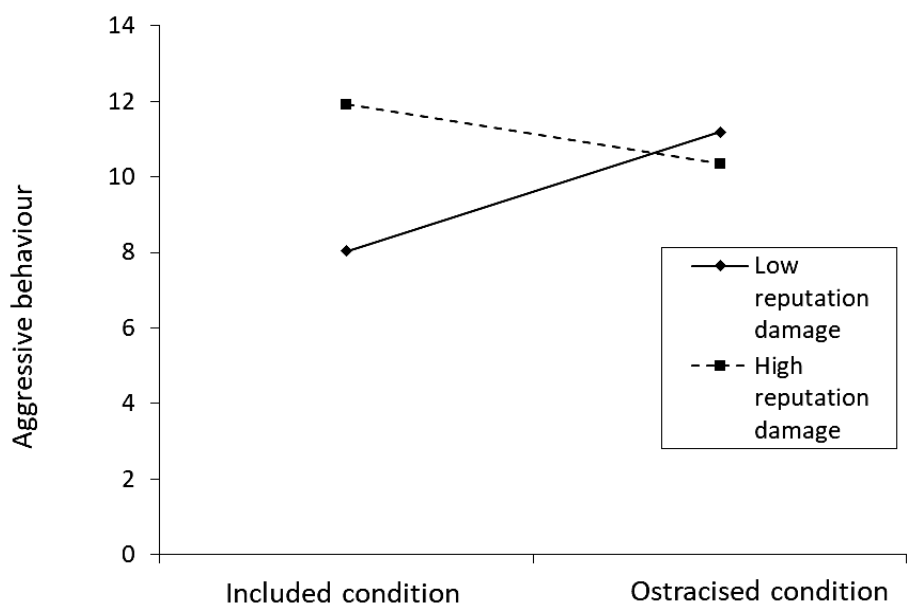

Figure 2. Rating of opponent's reputation damage as moderator for the effect of ostracism on aggressive behavior. Interaction plotted as recommended by J. F. Dawson

(http://www.jeremydawson.co.uk/slopes.htm).

behavior were proposed to mediate the effect of ostracism on change in post-aggression (i) negative affect, or (ii) positive affect, while controlling for rating of opponent's reputation damage. Participants' mood was calculated as a change score by subtracting the baseline mood from the subsequent mood.

The first serial mediation analysis explained $37.66 \%$ of the variance change in post-aggression negative affect (see Figure 3 Panel A). We found significant total indirect effect of ostracism on change in postaggression negative affect $(B=.20, S E=.07,95 \% \mathrm{CI}$ $[.07, .35])$. In partial support for Hypothesis 3 , the link between ostracism and change in post-aggression negative affect was mediated by the indirect effect of change in post-ostracism negative affect $(B=.18$, $S E=.07,95 \%$ CI $[.06, .34])$ but not by aggressive behavior ( $B=.001, S E=.02,95 \%$ CI [- .04, .05], ns.). The sequential path from ostracism -- change in postostracism negative affect --- aggressive behavior --change in post-aggression negative affect was marginally significant $(B=.01, S E=.01,95 \%$ CI [ - - .001, .03]).

The second analysis explained $8.57 \%$ of the variance change in post-aggression positive affect (Panel B Figure 3). The total indirect effect of ostracism on change in post-aggression positive affect was not significant $(B=.01, S E=.03,95 \%$ CI [- $.07, .07])$. This result was not surprising given that being aggressive appeared to influence positive affect for both ostracized and included participants in the same direction (see again Figure 1). Altogether, findings from the first and second serial mediation revealed that aggressive behavior triggered by negative affect after being ostracized 

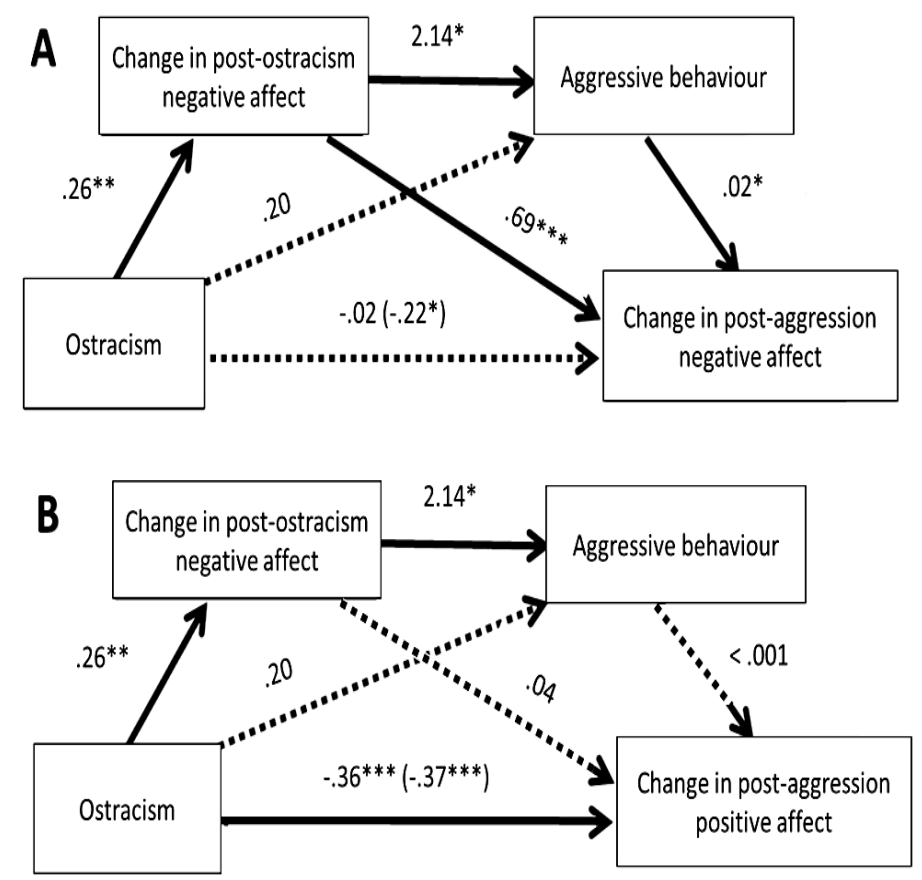

Figure 3. Serial mediation models of ostracism on change in post-aggression negative affect (Panel A) and positive affect (Panel B), using change in post-ostracism negative affect and aggressive behaviour as mediators, controlling for rating of opponent's reputation damage (based on 5,000 resamples with 95\% biascorrected CI). Values represent unstandardized regression coefficients. The value in parentheses represents the direct effect after controlling for the indirect effect. ${ }^{*} p<.05 ;{ }^{* *} p<.01 ;{ }^{* * *} p<.001$.
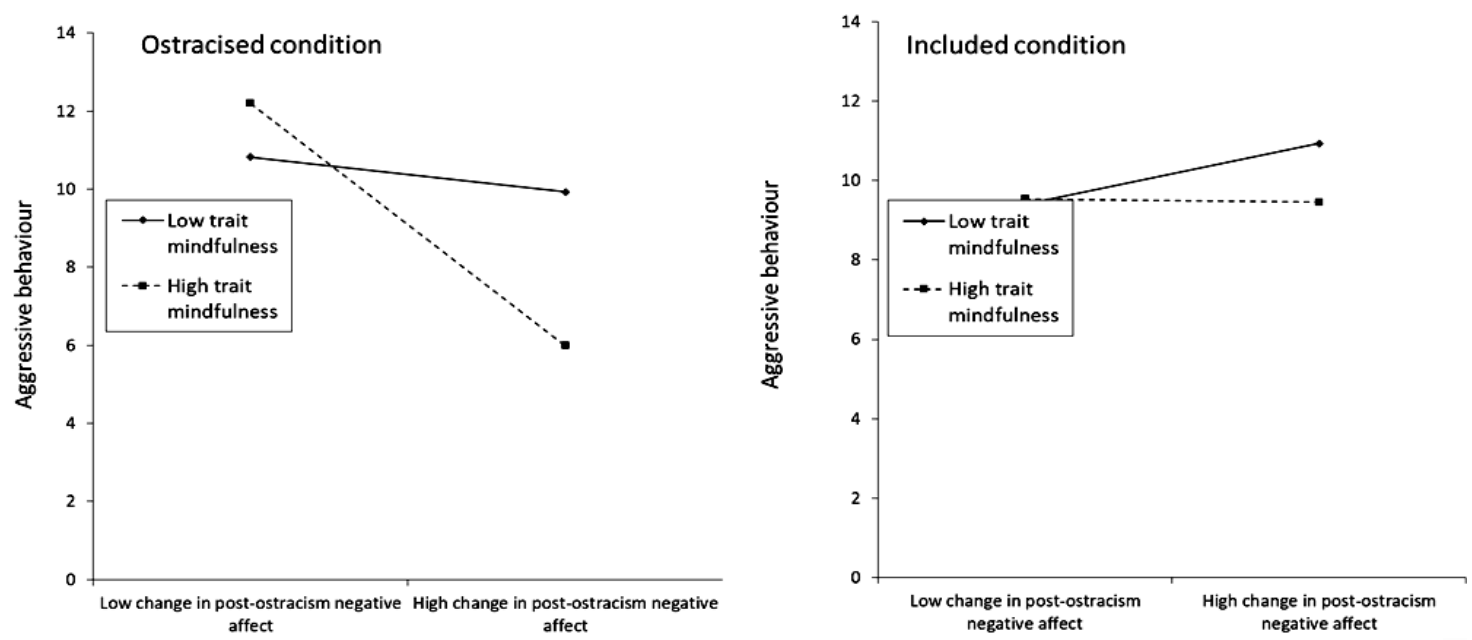

Figure 4. Trait mindfulness as moderator for the effect of change in post-ostracism negative affect on aggressive behavior for ostracised vs. inclusion condition. Interaction plotted as recommended by J. F.

Dawson (http://www.jeremydawson.co.uk/slopes.htm).

was more effective to restore participants' mood in terms of negative affect but not positive affect. In these analyses, rating of opponent's reputation damage predicted higher aggressive behavior $(B=1.72, S E$ $=.74,95 \%$ CI $[.24,3.19])$.

\section{Moderation of Trait Mindfulness}

We examined Hypothesis 4 on the moderating role of trait mindfulness by performing separate simple moderation analyses (PROCESS v3.3. "Model 1: 
Hayes, 2019, based on 5,000 resamples with 95\% bias-corrected $\mathrm{CI}$ ) for participants in the ostracism vs. inclusion conditions. We used change in postostracism negative affect as predictor, trait mindfulness as moderator, and aggressive behavior as outcome in each model. As expected, trait mindfulness significantly moderated the link between postostracism negative affect and aggressive behavior amongst ostracized participants $(B=-4.03, S E=1.77$, 95\% CI [- 7.57, -.50]) but not amongst included participants $(B=-2.84, S E=.96,95 \%$ CI $[-7.17,1.50]$, ns. $)$.

A simple slope test (Figure 4) indicated that for ostracized participants, the effect of change in postostracism negative affect on aggressive behavior was negative when trait mindfulness was high $(+1 \mathrm{SD} ; B$ $=-5.76, S E=1.92,95 \%$ CI $[-9.61,-1.91]$ ) but nonsignificant when trait mindfulness was low (-1 SD; $B=-3.08, S E=1.41,95 \%$ CI [- 3.65, 1.20], ns.). Thus supporting Hypothesis 4, ostracized participants who were more mindful displayed less aggression as the change in post-ostracism negative affect increased. Similar results were obtained when rating of opponent's reputation damage was included as covariate in the models, with an exception of a positive association between this rating and aggressive behavior amongst included participants $(B=3.64, S E=.96,95 \% \mathrm{CI}$ $[1.71,5.56])$.

\section{Discussion}

We experimentally manipulated participants' level of ostracism-based experience to investigate its serial impacts on mood and aggressive behavior. It should be noted that contrary to past lab-based studies (see Ren et al., 2018) and also to the replicated Chester and DeWall's (2016) experiment, our participants who had been ostracized by the Cyberball paradigm were as equally aggressive towards an opponent in the CRTT as included participants. A similar divergence was previously reported by Beyer et al. (2014), who found no direct effect of ostracism on aggression unless the participants believed that their Cyberball opponent committed ostracism deliberately. In our study, we did not measure participants' interpretation of the context of ostracism. Rather, we calculated the rating of opponent's behavior during the CRTT (i.e., rating of reputation damage), and found that ostracized participants were in fact more aggressive (i.e., delivered more severe noise blast) than included participants once they proceeded to rate their opponent as being more fair, less aggressive, and more skillful. For included participants, a better rating of opponent's reputation simply corroborated with lower level of noise blast. These seemingly paradoxical courses of responses amongst ostracized participants (i.e., aggress first, better rating of opponent's reputation later) suggest that ostracism may trigger retaliatory aggression only when it is followed by the chances of redemption.

Supporting Williams' (2009) temporal framework, McDonald and Donnellan (2012) found that immediate reactions to ostracism as induced by the Cyberball paradigm represent a "strong" situation that triggers uniform reactions. In the current study we established that after the ostracism manipulation, ostracized participants were lower in positive affect and higher in negative affect compared to included participants. Interestingly, although the effect of ostracism on aggressive behavior was conditioned upon the later opportunity to rate the opponent, ostracized participants reported reductions in negative affect and increases in positive affect after the CRTT. Not only did their post-aggression mood return to the baseline levels prior to being ostracized, but their negative affect was also comparable to that of included participants. Moreover, higher change score in post-ostracism negative affect led to higher initial aggressive response, and then led to higher change on post-aggression negative affect, albeit this temporal sequence was marginally significant. It could be that rather than using the opportunity to blast an aversive noise to the ostracizer as act of revenge or punishment, ostracized participants might have chosen to refrain from behaving aggressively as act of forgiveness. This possibility was supported by the findings that no significant differences in aggressive behavior were observable between ostracized and included participants, and even when some ostracized participants chose to aggress this act was followed by positive evaluation (good ratings) to their opponents.

It should be acknowledged that individuals from collectivistic orientation might not perceived exclusion as threatening to the interdependent self-construal (Markus \& Kitayama, 1991). This is supported by the finding that compared with people with individualistic orientation, people with collectivistic orientation did not differ in their behavioral intentions between ostracism and inclusion conditions (Pfundmair, Graupmann, Frey, \& Aydin, 2015). While aggression is to be expected if the fundamental needs of control and meaningful existence are threatened, pro-social reactions have been reported amongst ostracized participants whose needs of belonging and self-esteem are 
threatened (Wesselmann, Ren, \& Williams, 2015). Our study focused only on post-ostracism aggression; however, it is plausible that as members of collectivistic culture our ostracized participants were in fact more prone to fortify their inclusionary needs (belonging and self-esteem) through the act of forgiving the ostracizer.

An fMRI study of reactions to Cyberball concludes that granting forgiveness activated neural networks related to social cognition and cognitive control (Will, Crone, \& Güroğlu, 2014). As a result of suppressing spontaneous aggressive responses to hurtful actions, the emotional experience of these actions is positively changed (Ricciardi et al., 2013). Although speculative, this might explain why our ostracized participants felt much better after such act has been chosen. For the included participants, being involved in the CRTT merely created fluctuations in their mood (i.e., higher in both positive and negative affect after the CRTT).

As an extension of Chester and DeWall's (2016) design, we included measure of individual differences in mindfulness to examine its role on negative affect and aggressive behavior. We found that those who were more mindful reported lower negative affect at all time-point of the study (i.e., baseline, post-ostracism, and post-aggression). Crucially, trait mindfulness had a null relationship with aggressive behavior, yet it moderated the relationship between change in postostracism negative affect and aggressive behavior. From the perspective of person $\mathrm{X}$ situation interaction models (e.g., Marshall \& Brown, 2006; Schmitt et al., 2013), initial differences in behavior between individuals become increasingly larger as they move to a "weak" situation. Although the uniform initial reactions towards ostracism were mood impairment, it appeared that the change in post-ostracism negative affect itself represented a weak situation for ostracized participants. Trait mindfulness might represent a "weak" person, because participants high in trait mindfulness responded less aggressively once the change in post-ostracism negative affect was high but not when it was low. Consequently, the benefit of trait mindfulness appeared to function in a threshold-like manner to the change in post-ostracism negative affect.

\section{Limitations of the Study}

Our study has a number of limitations. According to Williams' (2009) temporal framework, detecting ostracism requires only the slightest representation of any cues of ostracism that will lead the ostracized to focus on recovering via various cognitive or behavioral tactics. As in Chester's and DeWall's (2016) experiment, the only tactic we provided was for the participants to aggress (or to not aggress i.e., the nonaggressive option). Future work should explore other possible behavioral responses such as conformity and seeking solitude. Second, we did not actively induce participants' level of mindfulness. Trait and state mindfulness appear to contribute unique variance to lower aggressiveness (Eisenlohr-Moul, Peters, Pond, $\&$ DeWall, 2016), suggesting that the underlying mechanisms for the efficacy of mindfulness might depend on the operationalization of this construct. To establish for whom mindfulness is more fruitful as a clinical intervention, it is important to distinguish mindfulness as a natural predisposition from its deliberate practice (Wheeler, Arnkoff, \& Glass, 2015). Third, the present study utilized an undergraduate sample that may not be at highest risk for direct physical aggression. Future study could involve participants from high risk youth and adult offender populations. Finally, our participants' rating of opponent's reputation damage consistently predicted higher aggressive behavior beyond the impact of ostracism. A similar rating method has been used as a measure of indirect aggression in Lawrence's and Hutchinson's (2014) study, since a negative judgment would reflect an immediate intent to cause harm to the target, which corresponds to Anderson's and Bushman's (2002) widely accepted definition of aggression. Since children from collectivistic culture are less likely to resort to direct methods of retaliation (Bergmüller, 2013), more research is timely to explore the effect of ostracism on various types of indirect aggression.

\section{Conclusions}

The current study combined standardized lab-based paradigm adapted from Western researchers to establish the causality between ostracism (i.e., Cyberball: Williams et al., 2000) and direct physical aggression (i.e., Competitive Reaction Time Task [CRTT]: Taylor, 1967), while exploring the potential role of trait mindfulness (Mindfulness Attention Awareness Scale [MAAS]: Brown \& Ryan, 2003) as an alternative emotion regulation strategy towards ostracism. Williams (2009) proposes that aggression is likely to be preferred when the ostracized seeks to enhance his or her needs of control and belonging. Unlike the replicated study from Chester and DeWall (2016), we found that ostracized participants were more aggressive than included participants only when they were provided with later opportunity to deliver a better rating for the 
opponent, presumably as an act of restoring control. Whilst it is difficult to raise any definitive conclusion based on the trivial effect of ostracism on aggression per se, one could argue that these complex mechanisms had recovered participants' mood in terms of negative affect. Although ostracism initially triggered unequivocal mood impairment, participants high in trait mindfulness responded less aggressively particularly when the change in post-ostracism negative affect was high. As such, it is plausible for mindful individuals to be more responsive to their ostracism-related experiences once these experiences become more intense.

\section{Acknowledgement}

Funding for this research was provided by the Faculty of Social and Political Sciences of Universitas Brawijaya.

\section{References}

Anderson, C. A. \& Anderson, K. B. (2008). Men who target women: specificity of target, generality of aggressive behavior. Aggressive Behavior, 34(6), 605-622. https://doi.org/10.1002/ab.20274

Anderson, C. A., \& Bushman, B. J. (2002). Human aggression. Annual Review of Psychology, 53(1), 27-51. https://doi.org/10.1146/annurev.psych.53.100 901.135231

Baer, R. A. (2003). Mindfulness training as a clinical intervention: A conceptual and empirical review. Clinical Psychology: Science and Practice, 10(2), 125-143. https://doi.org/10.1093/clipsy.bpg015

Bergmüller, S. (2013). The relationship between cultural individualism-collectivism and student aggression across 62 countries. Aggressive Behavior, 39(3), 182-200. https://doi.org/10.1111/10.1002/ ab. 21472

Beyer, F., Münte, T. F., \& Krämer, U. M. (2014). Increased neural reactivity to socio-emotional stimuli links social exclusion and aggression. Biological Psychology, 96(1), 102-110. https://doi.org/10.1016 /j.biopsycho.2013.12.008

Blackhart, G. C., Nelson, B. C., Knowles, M. L., \& Baumeister, R. (2009). Rejection elicits emotional reactions but neither causes immediate distress nor lowers self-esteem: A meta-analytic review of 192 studies on social exclusion. Personality and Social Psychology Review, 13(4), 269-309.

Brown, K. W., \& Ryan, R. M. (2003). The benefit of being present: Mindfulness and its role in psycho- logical well-being. Journal of Personality and Social Psychology, 84(4), 822-848. https://doi.org/10.10 37/0022-3514.84.4.822

Chester, D. S., \& DeWall, C. N. (2016). Combating the sting of rejection with the pleasure of revenge: A new look at how emotion shapes aggression. Journal of Personality and Social Psychology, 112(3), 413-430. https://doi.org/10.1037/pspi0000080

Denson, T. F. (2015). Four promising psychological interventions for reducing reactive aggression. Current Opinion in Behavioral Sciences, 3, 136141. https://doi.org/10.1016/j.cobeha.2015.04.003

Eisenlohr-Moul, T. A., Peters, J. R., Pond, R. S., Jr, \& DeWall, C. N. (2016). Both trait and state mindfulness predict lower aggressiveness via anger rumination: A multilevel mediation analysis. Mindfulness, 7(3), 713-726. https://doi.org/10.10 07/s12671-016-0508-x

Elson, M. (2016). FlexibleMeasures.com: Competitive reaction time task. https://doi.org/10.17605/OSF. $\mathrm{IO} / 4 \mathrm{G} 7 \mathrm{FV}$

Forbes, G., Zhang, X., Doroszewicz, K., \& Haas, K. (2009). Relationships between individualism-collectivism, gender, and direct or indirect aggression: A study in China, Poland, and the US. Aggressive Behavior, 35(1), 24-30. https://doi.org/10.1002/ab.20292

Frewen, P. A., Evans, E. M., Maraj, N., Dozois, D. J. A., \& Partridge, K. (2008). Letting go: Mindfulness and negative automatic thinking. Cognitive Therapy and Research, 32(6), 758-774. https://doi.org/10. 1007/s10608-007-9142-1

Gerber, J., \& Wheeler, L. (2009). On being rejected: A meta-analysis of experimental research on rejection. Perspectives on Psychological Science, 4(5), 468488. https://doi.org/10.1111/j.1745-6924.2009.01158.x

Hartgerink, C. H. J., van Beest, I., Wicherts, J. M., \& Williams, K. D. (2015). The ordinal effects of ostracism: A meta-analysis of 120 Cyberball studies. PLoS ONE, 1O(5). https://doi.org/10.1371/journal. pone. 0127002

Hayes, A. F. (2019). PROCESS version 3.3. [Computer macro for SPSS]. Retrieved from http://process macro.org/download.html

Kong, D. T. (2016). Ostracism perception as a multiplicative function of trait self-esteem, mindfulness, and facial emotion recognition ability. Personality and Individual Differences, 93, 68-73. https://doi. org/doi:10.1016/j.paid.2015.08.046

Kross, E., Berman, M. G., Mischel, W., Smith, E. E., \& Wager, T. D. (2011). Social rejection shares somatosensory representations with physical pain. Proceedings of the National Academy of Sciences 
of the United States of America, 108(15), 6270-5. https://doi.org/10.1073/pnas.1102693108

Lawrence, C., \& Hutchinson, L. (2014). The impact of non-aggressive behaviour early in aggressive interactions: Sex differences in direct and indirect aggression in response to provocation. British Journal of Psychology, 105(1), 127-144. https://doi.org/ 10.1111/bjop.12020

Leary, M. R., Kowalski, R. M., Smith, L., \& Phillips, S. (2003). Teasing, rejection, and violence: Case studies of the school shootings. Aggressive Behavior, 29, 202-214. https://doi.org/10.1002/ab.10061

Markus, H. R., \& Kitayama, S. (1991). Culture and the self: Implications for cognition, emotion, and motivation. Psychological Review, 98, 224-253. https://doi.org/10.1037/0033-295X.98.2.224

Marshall, M. A. \& Brown, J. D. (2006). Trait aggressiveness and situational provocation: A test of the traits as situational sensitivities (TASS) model. Personality and Social Psychology Bulletin, 32, 1100-1113. https://doi.org/10.1177/0146167206288488

McCarthy, R. J., \& Elson, M. (2018). A conceptual review of lab-based aggression paradigms. Collabra: Psychology, 4(1), 4, 1-12. https://doi.org/10.1525 /collabra.104

McDonald, M. M., \& Donnellan, B. M. (2012). Is ostracism a strong situation? The influence of personality in reactions to rejection. Journal of Research in Personality, 46(5), 614-618. https://doi.org/10. 1016/j.jrp.2012.05.008

Molet, M., Macquet, B., Lefebvre, O., \& Williams, K. D. (2013). A focused attention intervention for coping with ostracism. Consciousness and Cognition, 22(4), 1262-1270. https://doi.org/10.1016/j.concog. 2013.08.010

Ren, D., Wesselmann, E. D., \& Williams, D. W. (2018). Hurt people hurt people: Ostracism and aggression. Current Opinion in Psychology, 19, 34-38. https:// doi.org/10.1016/j.copsyc.2017.03.026

Ricciardi, E., Rota, G., Sani, L., Gentili, C., Gaglianese, A., Guazzelli, M., \& Pietrini, P. (2013). How the brain heals emotional wounds: The functional neuroanatomy of forgiveness. Frontiers in Human Neuroscience, 7(839), 1-9. https://doi.org/10.3389 /fnhum.2013.00839

Sauer, S., Walach, H., Schmidt, S., Hinterberger, T., Lynch, S., Büssing, A., \& Kohls, N. (2013). Assessment of mindfulness: Review on state of the art. Mindfulness, 4(1), 3-17. https://doi.org/10.10 07/s12671-012-0122-5

Schmitt, M., Gollwitzer, M., Baumert, A., Blum, G., Gschwendner, T., Hofmann, W. \& Rothmund, T.
(2013). Proposal of a nonlinear interaction of person and situation (NIPS) model. Frontiers in Psychology, 4(499), 1-9. https://doi.org/10.3389/ fpsyg.2013.00499

Silarus, A. (2015). Sadar penuh, hadir utuh. Jakarta: TransMedia Pustaka.

Sleegers, W. W. A., Proulx, T., \& Beest, I. V. (2016). The social pain of Cyberball: Decreased pupillary reactivity to exclusion cues. Journal of Experimental Social Psychology, 69, 187-200. https://doi.org/ 10.1016/j.jesp.2016.08.004

Sommer, F., Leuschner, V., \& Scheithauer, H. (2014). Bullying, romantic rejection, and conflicts with teachers: the crucial role of social dynamics in the development of school shootings - a systematic review. International Journal of Development Science, 8, 3-24. https://doi.org/10.3233/DEV-140129

Taylor, S. (1967). Aggressive behavior and physiological arousal as a function of provocation and the tendency to inhibit aggression. Journal of Personality, 35(2), 297-310. https://doi.org/10.1111/j.1467-64 94.1967.tb01430.x

Twenge, J. M., Baumeister, R. F., Tice, D. M., \& Stucke, T. S. (2001). If you can't join them, beat them: Effects of social exclusion on aggressive behaviors. Journal of Personality and Social Psychology, 81, 1058-1069. https://doi.org/10.10 37/ 0022-3514.81.6.1058

Watson, D., Clark, L. A., \& Tellegen, A. (1988). Development and validation of brief measures of positive and negative affect: The PANAS scales. Journal of Personality and Social Psychology, 54(6), 1063-1070. https://doi.org/10.1037/0022-35 14.54.6.1063

Watson, D., \& Tellegen, A. (1985). Toward a consensual structure of mood. Psychological Bulletin, 98, 219235. https://doi.org/10.1037/0033-2909.98.2.219

Wesselmann, E. D., Ren, D., \& Williams, K. D. (2015). Motivations for responses to ostracism. Frontiers in Psychology, 6(40), 1-5. https://doi.org/10.3389 /fpsyg.2015.00040

Wesselmann, E. D., \& Williams, K. D. (2017). Social life and social death: Inclusion, ostracism, and rejection in groups. Group Processes and Intergroup Relations, 20(5), 693-706. https://doi.org/10.1177/ 1368430217708861

Wheeler, M. S., Arnkoff, D. B., \& Glass, C. R. (2015). What is being studied as mindfulness meditation? Nature Reviews Neuroscience, 17(1), 59. https:// doi.org/10.1038/nrn.2015.6

Will, G.-J., Crone, E. A., \& Güroğlu, B. (2014). Acting on social exclusion: Neural correlates of punishment 
and forgiveness of excluders. Social Cognitive and Affective Neuroscience, 10, 209-218. https://doi. org/10.1093/scan/nsu045

Williams, K. D. (2007). Ostracism. Annual Review of Psychology, 58, 425-452. https://doi.org/10.11 46/annurev.psych.58.110405.085641

Williams, K. D. (2009). Ostracism: A temporal needthreat model. In M. P. Zanna (Ed.), Advances in experimental social psychology, Vol. 41, (pp. 275314). San Diego, CA, US: Elsevier Academic Press. https://doi.org/10.1016/S0065-2601(08)00406-1

Williams, K. D, Cheung, C. K., \& Choi, W. (2000). Cyberostracism: Effects of being ignored over the Internet. Journal of Personality and Social Psychology, 79(5), 748-762. https://doi.org/10.1037/0022-3514. 79.5.748

Williams, K. D., Forgas, J. P., von Hippel, W., \& Zadro, L. (2005). The social outcast: An overview. In Williams, K. D., Forgas, J. P., von Hippel, W. (Eds.), The social outcast (pp. 1-15). New York, NY: Taylor \& Francis Group, LLC.

Yusainy, C., Chan, D. K. C., Hikmiah, Z., \& Anggono, C. O. (2019). Physical activity in Indonesian University students: The contradictory roles of dispositional mindfulness and self-control. Psychology, Health, and Medicine, 24(4), 446-455. https://doi.org/10. 1080/13548506.2018.1546015

Yusainy, C., Ilhamuddin, Ramli, A. H., Semedi, B. P., Anggono, C. O. Mahmudah, M. U., \& Ramadhan,
A. R. (2018). Between here-and-now and hereafter: Mindfulness sebagai pengawal orientasi terhadap kehidupan dan ketakutan terhadap kematian [Between here-and-now and hereafter: Navigating lifeorientation and fear of death through mindfulness]. Jurnal Psikologi Fakultas Psikologi Universitas Diponegoro, 17(1), 18-30. https://doi.org/10.1471 0/jp.17.1.18-30

Yusainy, C., \& Lawrence, C. (2014). Relating mindfulness and aggression to harm to the self and to others. Personality and Individual Differences, 64(1), 78-83. https://doi.org/10.1016/j.paid.2014. 02.015

Yusainy, C., \& Lawrence, C. (2015). Brief mindfulness induction could reduce aggression after depletion. Consciousness and Cognition, 33(1), 125-134. https://doi.org/10.1016/j.concog.2014.12.008

Yusainy, C., Nurwanti, R., Dharmawan, I. R. J, Andari, R., Mahmudah, M. U., \& Tiyas, R. R., Husnaini, B. H. M., \& Anggono, C. O. (2018). Mindfulness sebagai strategi regulasi emosi. Jurnal Psikologi Fakultas Psikologi Universitas Diponegoro, 17(2), 174-188. https://doi.org/10.14710/jp.17.2.174-188

Yusainy, C., \& Wicaksono, W. (2019). Post-depletion aggression restrained: Replicability of brief mindfulness induction in Indonesian sample. Jurnal Psikologi Fakultas Psikologi Universitas Gadjah Mada, 46(1), 1-18. https://doi.org/10.22146/jpsi. 36103 